\title{
Review \\ Glucocorticoid Signaling and Epigenetic Alterations in Stress-Related Disorders
}

\author{
Niki Mourtzi ${ }^{1}$, Amalia Sertedaki ${ }^{1}$ and Evangelia Charmandari ${ }^{1,2, *(\mathbb{D})}$ \\ 1 Division of Endocrinology, Metabolism and Diabetes, First Department of Pediatrics, "Aghia Sophia" \\ Children's Hospital, National and Kapodistrian University of Athens Medical School, 11527 Athens, Greece; \\ nikimourtzi23@gmail.com (N.M.); aserted@med.uoa.gr (A.S.) \\ 2 Division of Endocrinology and Metabolism, Center of Clinical, Experimental Surgery and Translational \\ Research, Biomedical Research Foundation of the Academy of Athens, 11527 Athens, Greece \\ * Correspondence: evangelia.charmandari@googlemail.com
}

Citation: Mourtzi, N.; Sertedaki, A.; Charmandari, E. Glucocorticoid Signaling and Epigenetic Alterations in Stress-Related Disorders. Int. J Mol. Sci. 2021, 22, 5964. https:// doi.org/10.3390/ijms22115964

Academic Editor: Matthew G. Frank

Received: 26 April 2021

Accepted: 29 May 2021

Published: 31 May 2021

Publisher's Note: MDPI stays neutral with regard to jurisdictional claims in published maps and institutional affiliations.

Copyright: (c) 2021 by the authors. Licensee MDPI, Basel, Switzerland. This article is an open access article distributed under the terms and conditions of the Creative Commons Attribution (CC BY) license (https:// creativecommons.org/licenses/by/ $4.0 /)$.
Abstract: Stress is defined as a state of threatened or perceived as threatened homeostasis. The welltuned coordination of the stress response system is necessary for an organism to respond to external or internal stressors and re-establish homeostasis. Glucocorticoid hormones are the main effectors of stress response and aberrant glucocorticoid signaling has been associated with an increased risk for psychiatric and mood disorders, including schizophrenia, post-traumatic stress disorder and depression. Emerging evidence suggests that life-stress experiences can alter the epigenetic landscape and impact the function of genes involved in the regulation of stress response. More importantly, epigenetic changes induced by stressors persist over time, leading to increased susceptibility for a number of stress-related disorders. In this review, we discuss the role of glucocorticoids in the regulation of stress response, the mechanism through which stressful experiences can become biologically embedded through epigenetic alterations, and we underline potential associations between epigenetic changes and the development of stress-related disorders.

Keywords: stress response; glucocorticoids; epigenetics; stress-related disorders

\section{Introduction}

Stress is defined as a state of threatened or perceived as threatened homeostasis. A broad spectrum of extrinsic or intrinsic, real or perceived stressful stimuli, called 'stressors', activates a highly conserved system, the 'stress system', which adjusts homeostasis through central and peripheral neuroendocrine responses. The stress response depends on highly complex and tightly-regulated processes and involves the cross-talk of molecular, neuronal and hormonal circuits [1]. The well-tuned coordination of these systems is indispensable for an organism in order to adapt to stressors and re-establish homeostasis (adaptive stress response) [2].

In mammals, glucocorticoid hormones are the main central effectors of the stress response, playing a crucial role in the effort of an organism to maintain its homeostasis during periods of stress [1]. Aberrant glucocorticoid signaling in response to stressors can lead to sub-optimal adaptation of an organism to stress events, a state that has been defined as cacostasis or allostasis [2]. When an organism falls into cacostasis, it strives to find ways to survive and maintain its stability outside of the normal homeostatic range, and the cost that it has to pay for this purpose is termed allostatic or cacostatic load [2].

Emerging evidence suggests that exposure to early-life stress events may alter the epigenomic landscape, which is defined as changes in the regulation of gene expression without changes to the DNA sequences [3]. The long-lasting nature of epigenetic changes led the scientific community to propose that glucocorticoid secretion in response to stress, as well as genes involved in the glucocorticoid signaling pathway, play a fundamental role in shaping a form of epigenetic memory through which stressful experiences become 
biologically embedded [3]. Critically, transcriptional dysregulation caused by aberrant epigenetic changes in glucocorticoid-related genes has been pathophysiologically linked with the emergence of a host of stress-related disorders [4].

The current review provides an update on the (a) molecular mechanisms of glucocorticoid action and the mechanisms through which glucocorticoid signaling mediates stress response; (b) the glucocorticoid-induced epigenetic changes on genome integrity during stress; and (c) existing evidence that links glucocorticoid-interceded epigenetic alterations with stress-related disorders.

\section{Glucocorticoid Signaling via GRs and MRs upon Stress Response}

The stress response is primarily mediated by the hypothalamic-pituitary-adrenal (HPA) axis-, as well as by effectors acting on peripheral organs [2,5-7]. Upon stressinduced activation, the HPA axis stimulates the release of adrenocorticotropic hormone (ACTH) that drives the adrenal secretion of glucocorticoids in the blood circulation [8] (Figure 1). Glucocorticoids exert their effects on target organs mainly through binding and activation of two types of receptors, the mineralocorticoid (MR) and the glucocorticoid (GR) receptor [1].

STRESS RESPONSE

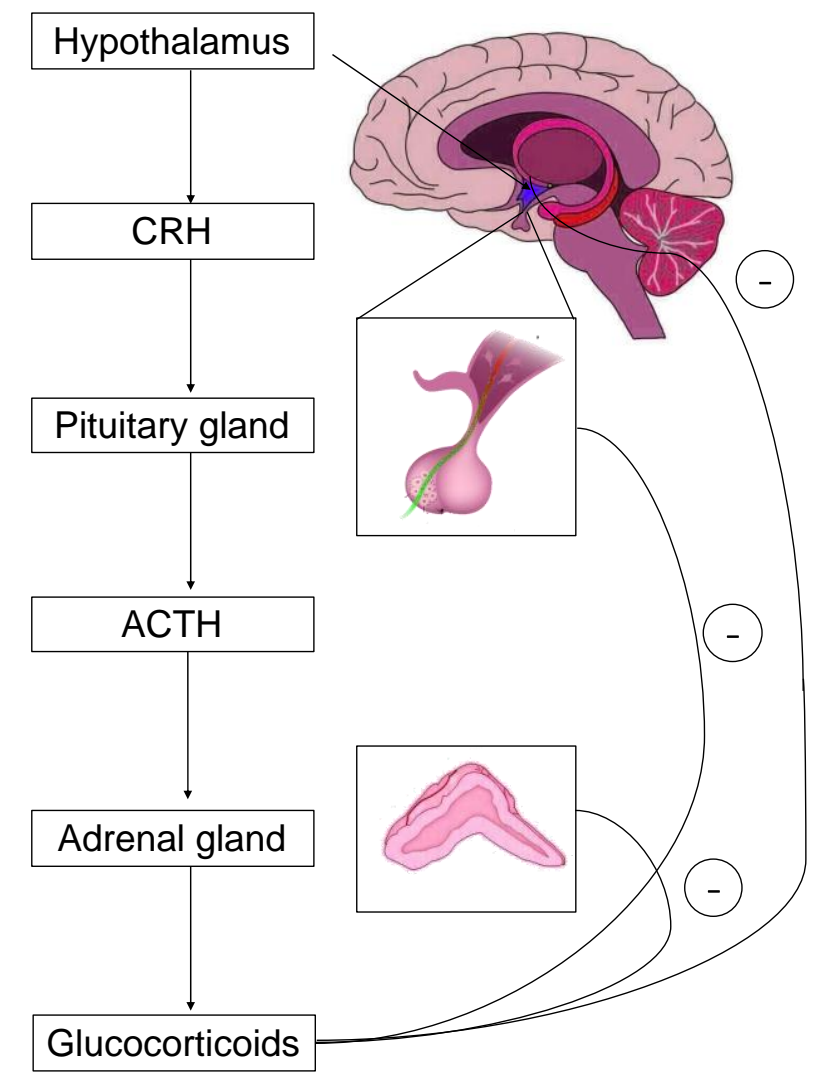

Figure 1. The hypothalamic-pituitary-adrenal (HPA) axis is the primary effector of a stress response. Critical hormones and organs are shown, whereas cycles with the negative symbol indicate negative feedback mechanisms.

On the one hand, glucocorticoids can have a generalized impact on multiple organs through binding to GRs that are abundant in almost every mammalian tissue, through genomic and nongenomic mechanisms [9]. Regarding the genomic-dependent pathway, GRs can regulate the expression of a wide variety of genes either through direct binding in glucocorticoid response elements (GREs) of GC-responsive genes [10] or through 
physical interaction with transcription factors [11]. In contrast to the genomic actions of GC that occur within hours or days [12], GRs can also exert rapid actions, which take place within seconds or minutes, through nongenomic mechanisms that do not involve GRs transcriptional activity and are not mediated by the genome [12]. The nongenomic actions of GCs are primarily mediated via membrane GRs (mGRs), a different isoform of the classic GR (termed as GR $\gamma$ ) that trigger the activation of kinase signaling pathways, such as the mitogen-activated protein kinase (MAPK) or the phosphatidylinositol 3-kinase (PI3K) cascades [13-15]. Moreover, GCs can directly influence the ion transport process by interlocating into the membranes of target cells [16] or bind and alter the activity of membrane receptors (such as ion channels, G-protein coupled receptors, enzyme-linked receptors) [13-15]. Examples of nongenomic GCs action during the stress response include rapid feedback inhibition of ACTH secretion from the anterior pituitary through mGR 28 , regulation of basal intracellular $\mathrm{Ca}^{2+}$ homeostasis29 and activation of ERK1/2 MAPK pathway, possibly through mGR action29.

On the other hand, MRs are predominantly expressed in limbic areas (hippocampus, amygdala and prefrontal cortex) together with GRs [17], and are characterized by a 10-fold higher binding affinity for glucocorticoids than GRs [18]. Due to the higher occupancy rate of MRs, it is thought that MRs play a more critical regulatory role in stress reactivity by setting the threshold of the HPA axis activation [19] rather than having an autonomous role as the main stress effector. Similar to GRs, the effects of GCs are mediated through MRs via genomic and nongenomic pathways [19]. MRs, upon GC binding, can act as transcription factors and alter the expression of several stress-associated genes, such as FK506 binding protein 5 (FKBP5) [20] glucocorticoid-induced leucine zipper (GILZ) [21], period circadian clock 1 (PERL1) [22] and serum/glucocorticoid regulated kinase 1 (SGK1) [23]. The rapid nongenomic action of MRs is mediated through membrane-bound MR (mMR) [24], including glutamate release from hippocampal CA1 neurons [25] and enhancement of glutamatergic transmission in basolateral amygdala neurons (BLA) [26].

\section{Functional Synergistic Network of MR and GR}

MRs and GRs interact with each other throughout the stress response, mediating distinct but complementary roles, and their synergistic action is considered essential for the maintenance and/or restoration of homeostasis. Interestingly, despite the fact that GRs and MRs recognize the same "GRE" sequence, their target genes, partially overlap and their effects may be different and sometimes opposites [27]. MRs are responsible for the appraisal of new information, activation of the stress reaction and memory retrieval of previous stress-associated strategies. Moreover, the genomic actions of classic MRs are responsible for setting the HPA axis sensitivity or threshold of the stress response [28].

On the other hand, GRs are indispensable for the termination of stress response, the energy mobilization, the recovery, and the memory storage of stressful experiences for future purposes. It has been suggested that the stress response could be divided into four phases, based on spatiotemporal features of nongenomic and genomic GCs actions $[27,29,30]$ (Figure 2).

Phase 1-Basal: At the basal state, intracellular MRs are occupied with low, nonstress concentrations of GCs, owing to their strong GC-binding affinity. The secretion of GCs following a stress event allows the additional binding of GCs to the lower-affinity GRs, which are progressively activated as the concentrations of GCs are further increasing [31] Thus, the constant GC occupation of MRs determines the threshold for activation of stress response, while the short-term activation of GRs provides flexibility to the stress system to respond to sudden GC changes as they occur [32].

Phase 2-Onset: When a stressor factor that threatens homeostasis or perceives to do so appears, the hypothalamus releases CRH that triggers GC secretion from the adrenal cortex. Instantly, mMRs, through nongenomic actions, increase the levels of attention and vigilance in support of recognizing and assessing the risk of the new threat [33]. At the same time, the mMR-induced excitability of hippocampal neurons permits the memory 
retrieval of previous stress-coping strategies [34], while in the amygdala region, the fightand-flight response is activated though MRs actions that promote feelings of fear and anxiety $[34,35]$. Critically, the limbic MR activation determines the stress-coping style that is deployed, with mild-stress stimuli promoting a "thinking" strategy, which is conducted in the hippocampus, instead of a "doing" strategy that involves increased activation of the amygdala.

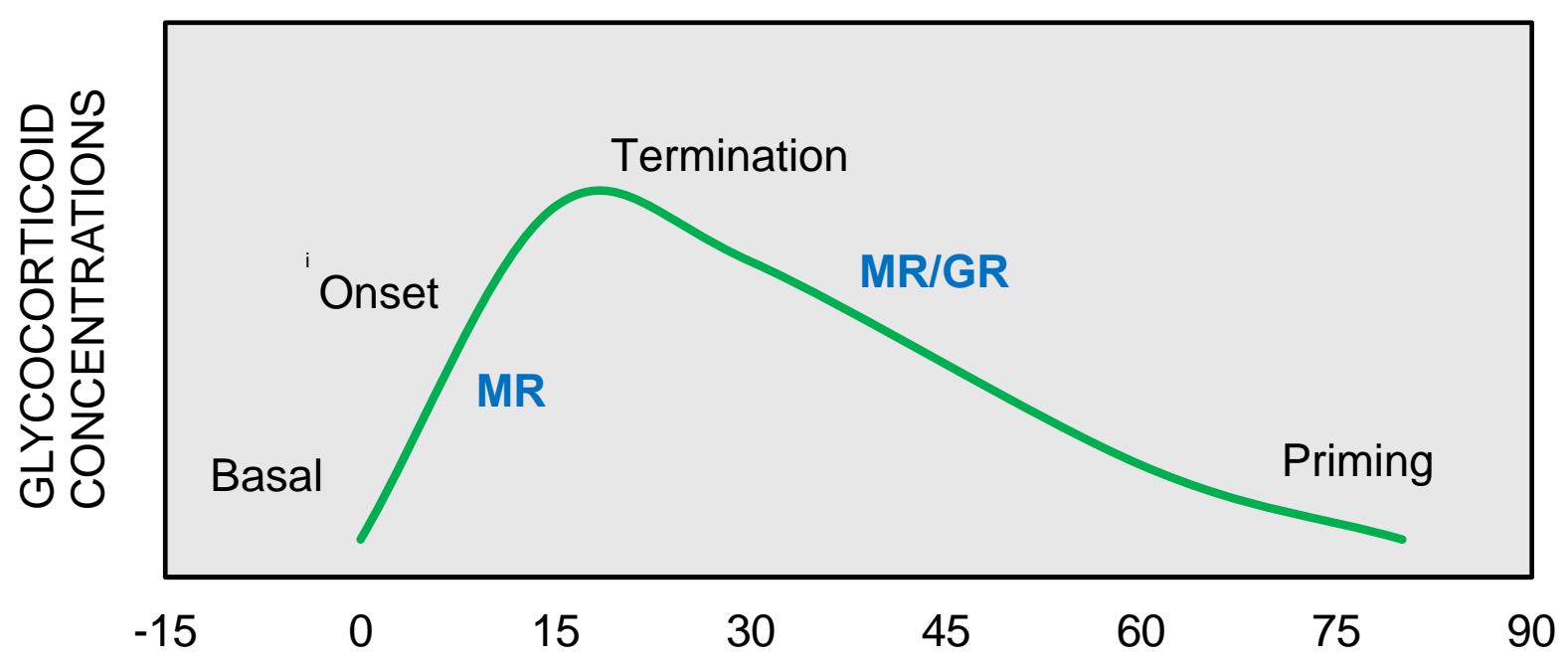

TIME (min)

Figure 2. The stress response can be divided into four phases: (1) Basal: intracellular MRs are occupied with low concentrations of glucocorticoids (GCs). (2) Onset: GCs secretion from the adrenal cortex in response to a stressful event. GCs bind to MRs, which are progressively activated as the concentrations of GCs increase (3) Termination: GRs are activated and mediate the termination of stress response by exerting negative feedback at the hypothalamic and anterior pituitary level (4) Priming: Stressful experiences will be stored through GRs action in hippocampus and prefrontal context for future use.

Phase 3-Termination: As the concentrations of GCs progressively increase during the stress response, low-affinity GRs become active and they exert negative feedback at the level of the hypothalamus and anterior pituitary, and contribute to the termination of stress response [36]. The termination is achieved through transcription-independent and transcription-dependent GR actions that mediate (a) fast negative feedback at the pituitary (ACTH inhibition) and hypothalamic levels (CHR inhibition) ( $<10 \mathrm{~min}$ ) [37], followed by (b) intermediate negative feedback acting on the paraventricular nucleus (PVN) of the hypothalamus ( $30 \mathrm{~min}-2 \mathrm{~h}$ ) and (c) slow and long-lasting negative feedback $(>3 \mathrm{~h}$ ) that involves suppression of pro-opiomelanocortin (POMC) expression, the ACTH precursor molecule [38]. In parallel, through transcriptional regulatory mechanisms, the GRs transmit the signal to multiple organs for the mobilization of energy resources in order to meet the energy demand of recovery to basal state [39].

Phase 4-Priming: The stressful experience, along with its selected coping style, is encoded and stored in the hippocampus and prefrontal context through the GRs actions for future use [40,41]. Memory consolidation of stress experience enables MR-mediated memory retrieval when similar situations arise in the future. During the priming stage, the GRs induce the activation of NF-KB NLRP3 inflammasome pathway [42], which may potentiate the neuroinflammatory response to a subsequent pro-inflammatory challenge [43]; this mechanism has been proposed to explain the paradoxical proinflammatory actions of GCs, traditionally considered as anti-inflammatory agents, observed in some clinical conditions [44]. 
Thus, MRs and GRs form a tightly co-regulated network that coordinates stress response and this observation led to the genesis of MR/GR balance hypothesis [30]. According to this hypothesis, an imbalance between the effects of GRs and MRs during the stress response may lead to dysregulation of the HPA axis and an inability to adapt to stressors and restore homeostasis, thereby conferring an increased vulnerability to a number of stress-related disorders [45].

\section{Epigenetic Alterations as a Cause of Dysregulation of the Stress Response}

An important mechanism that has been implicated in the development of MR/GR imbalance and HPA axis dysfunction pertains to the epigenetic alterations induced by major life stressors [46]. Epigenetics encompasses all the mechanisms influencing gene expression, without any change in DNA sequences [4], and is viewed as the interface between the genome and the environment [47]. These include DNA methylation, post-translation histone modifications, noncoding RNAs and three-dimensional changes in chromatin conformation [47]. It has been proposed that epigenetic modifications can be a part of a memory system that stores and transmits information about past stressful experiences to progeny cells, thus shaping cellular responses to subsequent stressor stimuli [46].

Regarding the mechanism linking epigenetic regulation with the stress response, it has been suggested and demonstrated through several functional studies that the GR activation by GCs instigates not only changes in gene transcription upon stress, but also alterations in DNA methylation patterns, with the most preeminent change being the DNA demethylation at or near the GRE elements [3].

Specifically, glucocorticoids can shape the epigenome through four major mechanisms, which primarily involve GR signaling (Figure 3) [48,49]: (a) GCs can rapidly and dynamically evoke demethylation of cytosine-guanidine dinucleotides (CpGs) at or near GREs [3]. The mechanism behind this action implicates GC-dependent transcriptional upregulation of enzymes that catalyze active demethylation (ex. TET family of 5-methylcytosine dioxygenases), as well as downregulation of DNA methyltransferases (ex. DNA methyltransferase 1, DNMT1) [50]. Although GR signaling during stress has been generally associated with demethylation processes, the action of GRs has also been linked with methylation of a number of genes [51]; (b) GCs can induce histone modifications, such as methylation and acetylation of histone proteins, via direct GR binding or via interaction of GRs with other transcription factors (TFs) that recruit histone acetyltransferases [3]. For instance, the TF RelB/p52 has been shown to recruit CBP binding protein and HDAC deacetylase that promote acetylation and deacetylation of histone 3 Lys in the promoter regions of $C R H$ and COX-2 genes [52]; (c) GCs can regulate expression patterns of several miRNAs, such as miR-218, miR-124, miR-29a, possibly through GR action, given that the genes encoding the altered miRNAs are enriched in predicted as GRE sites [53]; and (d) GCs can lead to chromatin remodeling via GR-activation, changing the accessibility of genomic regions to TFs [54].

Epigenetic alterations induced by GCs can appear at specific genomic loci but also at the genome-wide level [3]. For instance, prenatal exposure to untreated maternal depression has been linked with lower DNA demethylation patterns across the genome [55]. At the gene-specific level, epigenetic changes in genes involved in the HPA axis stress response pathway, have been consistently reported in a number of studies. In the context of stress responses or stress-related disorders, the most extensively studied epigenetically altered genes are the FKBP5, NR3C1, BDNF, SLC6A4 and OXTR [56,57].

Convergent evidence suggests that exposure to stress leads to hypomethylation of the gene encoding FK506 binding protein 51, FKBP5, which acts as a negative regulator of the GR signaling cascade [58]. In particular, it has been shown that FKBP5 interacts via the heat-shock protein HSP90 with GR and reduces the affinity of GR for binding to GCs by altering the folding of GR. Through this mechanism, FKBP5 suppresses the GR nuclear translocation and the concomitant action of GR as a transcription factor [59]. Thus, hypomethylation of $F K B P 5$ has been proposed to constitute a negative feedback mechanism 
that constrains the activity of the HPA axis [59]. Critically, FKBP5 is characterized by tissue expression specificity, with high baseline expression levels of the FKBP5 protein observed in the hippocampus but low levels in other areas, such as the hypothalamus [59]. The context-dependent expression of $F K B P 5$ has been shown to influence the degree of Fkbp5 mRNA induction following GC administration in mouse models [60]. In particular, regions characterized by low levels of FKBP5 protein at baseline (hypothalamus, amygdala) showed a higher fold-change increase in FKBP5 mRNA expression levels compared to regions with high FKBP5 baseline expression levels (hippocampus) [60]. The context-dependent expression of FKBP5 that dictates the tissue-specific response to stressors should be taken into account when we consider FKBP5 dysregulation as a risk factor for development of stress-related disorders and when we assess the effects of drugs inhibiting FKBP5, as we will discuss later.

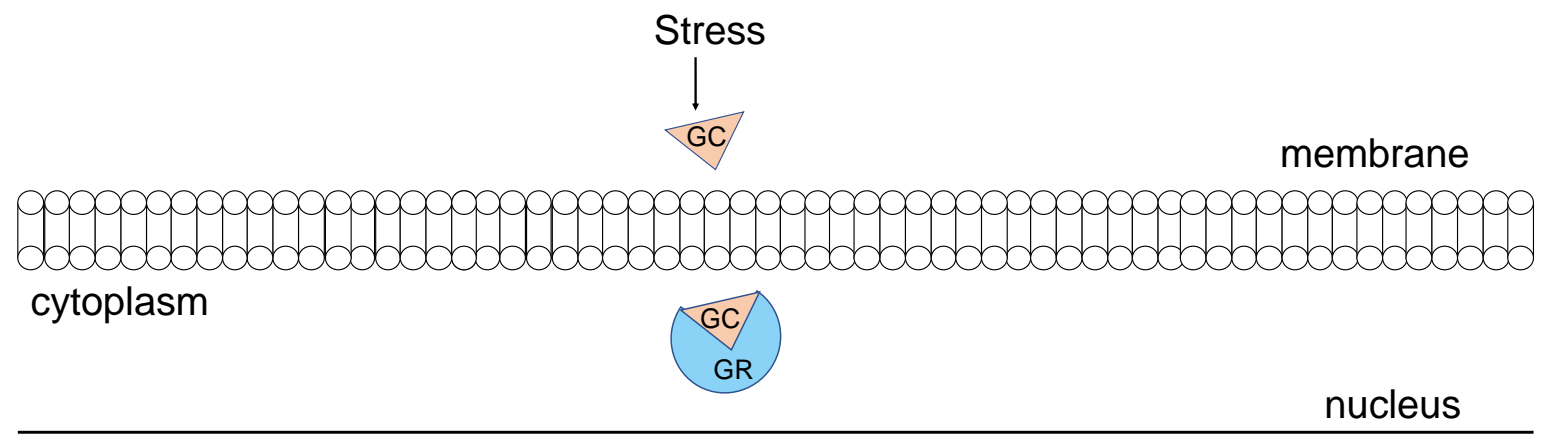

A)

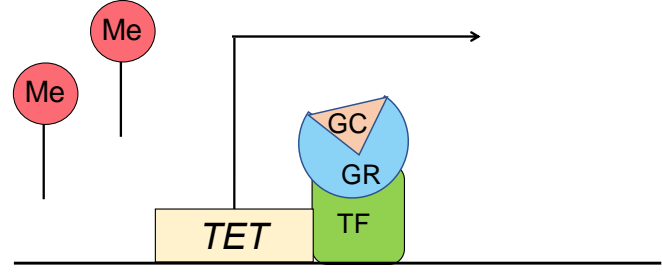

B)

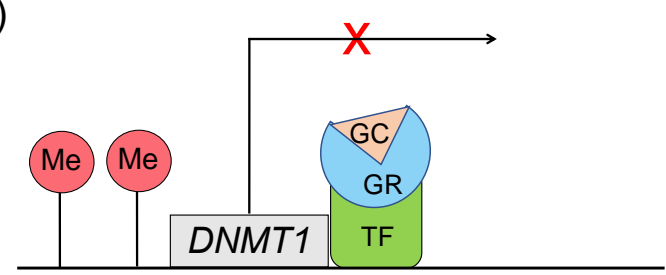

C)

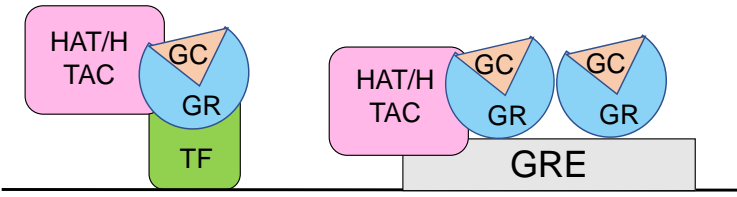

D)

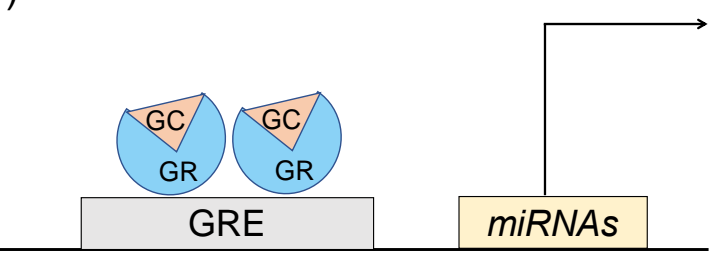

Figure 3. Mechanisms through which glucocorticoid-mediated activation of GR can induce epigenetic changes (A) GRs through interaction with transcription factors (TF) catalyze active demethylation of enzymes involved in demethylation processes, such as the TET family of 5-methylcytosine dioxygenases. (B) GRs catalyze active methylation of enzymes involved in methylation processes, such as DNMT (DNA methyltransferase 1, DNMT1). (C) GRs activation can induce histone modifications via direct GR binding on GRE elements or via interaction of GRs with TFs that recruit histone acetyltransferases. (D) GRs activation can regulate the expression of microRNAs, enriched in GRE elements. GC: glucocorticoid, GR: glucocorticoid receptor, GRE: glucocorticoid response elements, DNMT1: DNA methyltransferase 1, HAT: histone acetyltransferases, HDAC: histone deacetylase, ME: methionine, TET: ten-eleven translocation methylcytosine dioxygenases, TF: transcription factor.

The GR gene, NR3C1, has been extensively studied in the context of epigenetic regulation of the stress response. Findings from animal models, replicated in humans, point towards a stress-induced increased level of NR3C1 methylation that has been associated with decreased levels of NR3C1 expression [61]. Stress-induced epigenetic modification of the NR3C1 gene occurs across the lifespan, from prenatal life [3,7] to late adulthood [62], with the early and later life periods being more sensitive to stressors given that in these periods, we observe either rapid or less efficient epigenetic adaptation, respectively [3]. Crit- 
ically, it has been demonstrated that methylation changes occurring early in life can have long-term effects, impacting the plasticity of stress response mechanisms and jeopardizing the adaptation to future stressful situations [63].

$B D N F$ encodes the brain-derived neurotrophic factor that contributes to the neuronal plasticity of the brain by regulating the activity of several neurotransmitter receptors, such as GABA and tyrosine kinase B (TrkB) receptors, and plays a crucial role in learning and memory formation [64]. Animal models have shown that early-life stressors, as well as chronic stress in adulthood, induce methylation of $B D N F$ promoters I and IV leading to lower expression levels of $B D N F$ in the hippocampus $[65,66]$.

However, human studies have yielded conflicting results with respect to the methylation levels of $B D N F$ following exposure to stress, suggesting the involvement of compensatory mechanisms (such as medication) that may reverse this effect [67]. Moreover, reduction in the acetylation levels of histone $3(\mathrm{H} 3)$ at the promoters regions of BDNF following exposure to stress acts synergistically with methylation changes to downregulate $B D N F$ expression in the rat hippocampus [68].

Epigenetic changes in response to exposure to stress in early life have also been documented in the human serotonin transporter (5-HTT), which is encoded by SLC6A4 gene and is considered to be a key regulator of the serotoninergic system that regulates the stress response [69]. In particular, early life adversities, such as childhood abuse, have been associated with increased methylation status of SLC6A4 at exon 1 [70,71]. However, other studies failed to replicate this finding [72] or reported hypomethylation of SLC6A4 gene [73]. In addition, higher methylation levels of SLC6A4 in response to stress have been reported in carriers of 5-HTTLPR S (Short) allele, a polymorphism in the promoter region that confers susceptibility to stress [73]. The functional consequence of SLC6A4 methylation on mRNA levels appears to be multifactorial and possibly confounded by the presence of 5-HTTLPR polymorphism, given that the methylation status of SLC6A4 has not always been linked with HTT expression $[74,75]$.

Interestingly, epigenetic studies have demonstrated sex-dimorphic long-lasting methylation changes in various $\mathrm{CpG}$ sites of the oxytocin receptor gene (OXTR) following earlylife adverse events [76]. Specifically, exposure to adverse events during childhood and adolescence has been associated with higher methylation levels of CpG sites in OXTR gene only in females but not in males [76]. Therefore, females appear to be more prone to epigenetic changes in OXTR following stress events than males, which may reflect the sex-dependent effect of oxytocin on stress responsivity. Moreover, hypermethylation of CpG sites at OXTR gene has been reported in patients with anorexia-nervosa [77], as well as in patients with autism spectrum disorders (ASD) [78] compared with healthy control subjects. On the other hand, reduced levels of OXTR methylation in the cord blood of newborns has been associated with maternal depression symptoms in the second trimester of pregnancy [79]. Moreover, luciferase reporter assays have demonstrated that the methylation status of a $\mathrm{CpG}$ island, which is located in the first intron, regulates the transcriptional activity of OXTR [80]. Summary of the most recent findings about epigenetic modifications upon stress exposure are shown in Table 1.

Table 1. Summary of the most recent findings about epigenetic modifications upon stress exposure.

\begin{tabular}{ccccc}
\hline Gene & Reference & Species & Stressors & Epigenetic Changes \\
\hline \multirow{2}{*}{ FKBP5 } & Saito et al., 2020 [81] & Human & Childhood abuse & $\begin{array}{c}\text { demethylation of FKBP5 } \\
\text { intron 7 }\end{array}$ \\
\cline { 2 - 5 } & Misiak et al., 2020 [82] & Human & $\begin{array}{c}\text { Adverse childhood } \\
\text { experiences (ACEs) }\end{array}$ & demethylation of FKBP5 \\
\cline { 2 - 5 } & Ramo-Fernandez et al., 2019 [83] & Human & Childhood maltreatment & demethylation of FKBP5 \\
\hline
\end{tabular}


Table 1. Cont.

\begin{tabular}{|c|c|c|c|c|}
\hline Gene & Reference & Species & Stressors & Epigenetic Changes \\
\hline \multirow{3}{*}{ NR3C1 } & Borcoi et al., 2021 [84] & Human & $\begin{array}{c}\text { Food and nutritional security or } \\
\text { insecurity status }\end{array}$ & $\begin{array}{l}\text { hypermethylation of NR3C1 } \\
\text { 1F promoter }\end{array}$ \\
\hline & Pinheiro et al., 2021 [85] & Human & $\begin{array}{l}\text { Alcohol consumption, Body } \\
\text { mass index-BMI }\end{array}$ & $\begin{array}{l}\text { hypomethylation of NR3C1 } \\
\text { 1F promoter (alcohol } \\
\text { consumption), } \\
\text { hypermethylation of NR3C1 } \\
\text { 1F promoter (BMI) }\end{array}$ \\
\hline & Misiak et al., 2021 [86] & Human & Adverse childhood experiences & hypomethylation of NR3C1 \\
\hline \multirow{3}{*}{$B D N F$} & Duffy et al., 2020 [87] & Rat & Aversive caregiving & hypermethylation BDNF \\
\hline & Blaze et al., 2017 [88] & Rat & Caregiver maltreatment & hypermethylation BDNF IV \\
\hline & Niknazar et al., 2017 [89] & Rat & Preconception maternal stress & hypermethylation BDNF \\
\hline \multirow{3}{*}{ SLC6A4 } & Delano et al., 2021 [90] & Human & $\begin{array}{l}\text { Maternal community- } \\
\text { level deprivation }\end{array}$ & $\begin{array}{l}\text { hypermethylation of } 8 \mathrm{CpGs} \\
\text { SLC6A4 }\end{array}$ \\
\hline & Anurag et al., 2019 [91] & Human & $\begin{array}{c}\text { Early adversity (children } \\
\text { of alcoholics) }\end{array}$ & hypermethylation of SLC6A4 \\
\hline & Smith et al., 2017 [92] & Human & $\begin{array}{l}\text { Adverse neighborhood } \\
\text { environment }\end{array}$ & hypermethylation of SLC6A4 \\
\hline \multirow{3}{*}{ OXTR } & Kogan et al., 2019 [93] & Human & $\begin{array}{l}\text { Childhood adversity and } \\
\text { socioeconomic instability }\end{array}$ & hypermethylation of OXTR \\
\hline & Kogan et al., 2018 [94] & Human & Childhood adversity & hypermethylation of OXTR \\
\hline & Gouin et al., 2017 [95] & Human & Early life adversity (ELA) & $\begin{array}{l}\text { hypermethylation of OXTR } \\
\text { in females }\end{array}$ \\
\hline
\end{tabular}

\section{Epigenetic Changes and Stress-Related Disorders}

Epigenetic modifications constitute part of a mechanism through which stressful life experiences are embedded in an individual's biology, shaping the response to future threats [46]. More importantly, epigenetic changes have the intrinsic feature to persist over time, with a growing number of studies suggesting that they may predispose an individual to the development of stress-related phenotypes and diseases [46]. The causal link between epigenetic signatures and stress-related phenotypes has been unveiled by studies examining: (a) differences in methylation patterns of patients compared to controls, usually measured in peripheral tissues; and (b) if the observed differences in methylation status represent epigenetic signatures of stressful experiences occurring in the past.

Indeed, active and long-lasting demethylation of $F K B P 5$ gene associated with childhood abuse has been involved in the development of major depressive disorder [96]. Critically, the degree of the environmentally induced epigenetic changes has been shown to be influenced by the presence of risk alleles in FKBP5 gene that confer a higher risk for psychiatric disorders [96]. The interplay between genetic background-epigenetic environment seems to be more relevant during critical developmental periods where the epigenome shows heightened plasticity, such as in childhood, adolescence, or later life, since no association among them has been reported during adulthood [96].

Significant attention has been given to epigenetic modifications occurring in NR3C1 in response to environmental stressors, and their association with stress-related disorders. Studies exploring methylation changes in NR3C1, have investigated the effect of life-stress experiences occurring at different time periods, from as early as prenatal life to childhood and adulthood [97]. The majority of these studies reported significant hypermethylation at the exon $1 \mathrm{~F}$ promoter of NR3C1, which was also positively associated with the severity and the duration of an adverse event [98]. Subsequently, several studies showed that $N R 3 C 1$ methylation is associated with reduced levels of NR3C1 expression and with 
a lower number of GRs in the hippocampus [99]. It has been proposed that NR3C1 hypermethylation act as a mediator of the association between early life adversity and stress-related disorders [98]. In particular, prenatal stress due to maternal depression and early prenatal loss has been associated with hypermethylation of CpG sites from 35 to 37 , at hGR $1 \mathrm{~F}$ promoter, triggering the development of depression, bipolar disorder and suicidal behavior later in life [100].

In contrast, a significant hypomethylation pattern at hGR promoters $1 \mathrm{~B}$ and $1 \mathrm{C}$ has been observed in patients with post-traumatic stress disorder (PTSD) compared to controls [98]. A possible explanation for this discrepancy is that the timing of stress event may determine the direction of the effect, with adversities occurring early in life to promote hypermethylation of $\mathrm{NR} 3 \mathrm{C} 1$ and inhibition of hGR expression, and those appearing late in life to instigate demethylation of the same regions.

Recent studies in animal models of stress and depression revealed a decrease in Bdnf hippocampal mRNA levels, mediated by long-lasting methylation and acetylation changes in the promoter regions of $B d n f$ that were induced from perinatal exposure to methylmercury [101] or chronic social defeat stress conditions [102,103]. Moreover, in patients with depression, there was a significant decrease in BNDF protein levels compared to controls [104], while administration of antidepressants, such as selective serotonin reuptake inhibitors, stimulated BDNF expression and reversed the symptoms of depression [105]. Methylation-induced inhibition of BDNF has also been demonstrated in a study that examined genetic expression changes in the brains of suicide victims [105]. Furthermore, prevailing evidence supports higher methylation levels and decreased expression of $B D N F$ in patients with schizophrenia, a fact that may explain the impaired GABAergic signaling and the reduced hippocampal volume observed in this cohort compared to controls [106]. Mice carrying the rs6265, p.Val148Met minor variant (T), exhibit lower methylation levels of $B D N F$ following exposure to stress compared with controls subjects, because the $\mathrm{G}$ to $\mathrm{A}$ substitution abolishes a CpG site that is present in the wild type codon [107]. This finding was also shown in patients with schizophrenia, where Met carriers (CT or TT) were had $B D N F$ hypomethylation compared to noncarriers (CC), suggesting that an individual's genotypic background modulates the stress-induced epigenetic changes that may confer vulnerability to schizophrenia [108].

Major depressive disorder has also been associated with increased methylation levels of SLC6A2 [109] in subjects with a history of exposure to stress early in life, such as childhood maltreatment (CM) [71] or low socioeconomic status (SES) during adolescence [110]. In particular, greater methylation levels of CpG sites 11 and 12 of SLC6A2 gene were reported in individuals with a CM history [71] and greater methylation levels of SLC6A2 promoter were reported in individuals with a history of low SES during adolescence [110]. Both methylation patterns were associated with the emergence of depressive symptoms later in life [71,110]. As a potential mechanism, it has been proposed that reduced levels of SLC6A2 lead to dysfunction of serotonergic system by inhibiting serotonin uptake, which in turn may increase the susceptibility to depression [111].

An interesting interplay between genetic variation and epigenetic regulation in response to stress was shown in the study of Lei et al., where the methylation status of SLC6A2 correlated positively with depression symptoms only in individuals carrying the short risk allele of SLC6A2 [112]. However, the study of Alassari et al. [73] that examined the epigenetic effect of work-related stress on SLC6A2 methylation status revealed opposite results, with the high-stress environment being associated with hypomethylation of SLC6A2. As previously outlined, a possible explanation for this discrepancy is that the timing of stress exposure may dictate the direction of the effect, with stressors appearing early in life (CM, SES during adolescence) to promote hypermethylation of SLC6A2 and stressors occurring during adulthood to promote hypomethylation of SLC6A2.

The OXTR protein plays an important role in the regulation of social cognition (feelings of attachment and social recognition), as well as in the regulation of anxiety-related and social behaviors [79]. In view of its effect, it has been proposed to administrate intranasally 
OXT in individuals with social-affective deficits or psychiatric disorders [113]. In female subjects, adverse events in adulthood (financial pressure, high crime neighborhood) may induce methylation pattern changes in OXTR and may increase vulnerability to depression [113]. Furthermore, early traumatic events in childhood have been associated with altered methylation status of OXTR that may mediate the development of mood disorders in adulthood [114]. More specifically, hypomethylation of CpGs located in the promoter region of OXTR exon 1 and hypermethylation of sites located in OXTR intron 3 have been associated with depression and anxiety disorders in subjects with a history of childhood abuse [114].

A summary of the most recent findings about epigenetic modifications in patients with stress-related disorders are shown in Table 2.

Table 2. Summary of the most recent findings about epigenetic modifications in stress-related disorders.

\begin{tabular}{|c|c|c|c|c|}
\hline Gene & Reference & Species & Stress-related disorder & Findings \\
\hline \multirow{4}{*}{ FКBP5 } & Mihaljevicab et al., 2021 [115] & Human & Psychotic disorder & $\begin{array}{l}\text { (A) demethylation of FKBP5 } \\
\text { (B) genetic background } \\
\text { influence epigenetic } \\
\text { modifications }\end{array}$ \\
\hline & Kang et al., 2018 [116] & Human & $\begin{array}{l}\text { Post-Traumatic Stress } \\
\text { Disorder (PTSD) }\end{array}$ & $\begin{array}{l}\text { (A) demethylation of FKBP5 } \\
\text { (B) genetic background } \\
\text { influence epigenetic } \\
\text { modifications }\end{array}$ \\
\hline & Klinger-Konig et al., 2019 [117] & Human & Depression & $\begin{array}{l}\text { (A) demethylation of FKBP5 } \\
\text { associated with depression } \\
\text { (B) genetic background } \\
\text { influence epigenetic } \\
\text { modifications }\end{array}$ \\
\hline & Misiak et al., 2020 [82] * & Human & Psychotic disorders & $\begin{array}{l}\text { (A) demethylation of FKBP5 } \\
\text { associated with depression }\end{array}$ \\
\hline \multirow{4}{*}{ NR3C1 } & Borcoi et al., 2021 [84] * & Human & Depressive symptoms & $\begin{array}{l}\text { (A) hypermethylation of } \\
\text { NR3C1 1F promoter }\end{array}$ \\
\hline & Pinheiro et al., 2021 [85] * & Human & Depression & $\begin{array}{l}\text { (A) hypermethylation of } \\
\text { NR3C1 1F receptor }\end{array}$ \\
\hline & Bakusic et al., 2021 [118] & Human & Depression & $\begin{array}{c}\text { (A) hypermethylation } \\
\text { of NR3C1 }\end{array}$ \\
\hline & Misiak et al., 2021 [86] * & Human & Various stages of psychosis & $\begin{array}{l}\text { (A) hypomethylation of } \\
\text { NR3C1 in first-episode } \\
\text { psychosis patients (B) } \\
\text { hypermethylation of NR3C1 in } \\
\text { schizophrenia patients }\end{array}$ \\
\hline \multirow{4}{*}{$B D N F$} & Guo et al., 2021 [119] & Human & $\begin{array}{l}\text { Post-Traumatic Stress } \\
\text { Disorder (PTSD) }\end{array}$ & $\begin{array}{l}\text { (A) hypermethylation of BDNF } \\
\text { promoter (B) genetic } \\
\text { background influence } \\
\text { epigenetic modifications }\end{array}$ \\
\hline & Hossack et al., 2020 [120] & Human & $\begin{array}{l}\text { Post-Traumatic Stress } \\
\text { Disorder (PTSD) }\end{array}$ & $\begin{array}{l}\text { (A) hypomethylation of } \\
\text { BDNF promoter }\end{array}$ \\
\hline & Peng et al., 2019 [121] & Human & Depression & $\begin{array}{c}\text { (A) hypermethylation of BDNF } \\
\text { promoter at } 2 \text { CpGs }(\mathrm{B}) \\
\text { hypomethylation of BDNF } \\
\text { promoter at } 1 \mathrm{CpG}\end{array}$ \\
\hline & Shirata et al., 2020 [122] & Human & High sociotropy & $\begin{array}{l}\text { (A) hypermethylation of } \\
\text { BDNF promoter }\end{array}$ \\
\hline
\end{tabular}


Table 2. Cont.

\begin{tabular}{|c|c|c|c|c|}
\hline Gene & Reference & Species & Stress-related disorder & Findings \\
\hline \multirow{4}{*}{ SLC6A4 } & Sanwald et al., 2021 [123] & Human & Depression & $\begin{array}{l}\text { (A) hypermethylation } \\
\text { of SLC6A4 }\end{array}$ \\
\hline & Hossack et al., 2020 [120] & Human & $\begin{array}{l}\text { Post-Traumatic Stress } \\
\text { Disorder (PTSD) }\end{array}$ & $\begin{array}{l}\text { (A) hypomethylation } \\
\text { of SLC6A4 }\end{array}$ \\
\hline & Peng et al., 2019 [121] & Human & Depression & $\begin{array}{l}\text { (A) hypermethylation } \\
\text { of SLC6A4 }\end{array}$ \\
\hline & Schneider et al., 2017 [124] & Human & $\begin{array}{l}\text { Major Depression Disorder } \\
\text { (MDD) }\end{array}$ & $\begin{array}{l}\text { (A) hypomethylation } \\
\text { of SLC6A4 }\end{array}$ \\
\hline \multirow{4}{*}{ OXTR } & Nawjin et al., 2018 [125] & Human & $\begin{array}{l}\text { Post-Traumatic Stress } \\
\text { Disorder (PTSD) }\end{array}$ & $\begin{array}{l}\text { (A) hypermethylation of OXTR } \\
\text { in females }\end{array}$ \\
\hline & Kogan et al., 2018 [94] & Human & Substance use problem & (A) hypermethylation of OXTR \\
\hline & Ein-Dor et al., 2018 [126] & Human & Attachment avoidance & (A) hypermethylation of OXTR \\
\hline & Cappi et al., 2016 [127] & Human & $\begin{array}{l}\text { Obsessive-compulsive } \\
\text { disorder }\end{array}$ & (A) hypermethylation of OXTR \\
\hline
\end{tabular}

${ }^{*}$ Methylation status was also associated with previous stress-experience, see Table 1.

\section{Epigenetic Effects of Stress Exposure: Challenges and Confounders}

Studies investigating the epigenetic effects of stress experiences on the methylation status of stress-related genes sometimes report conflicting results about the direction of epigenetic effect (hypomethylation or hypermethylation) or fail to replicate their findings. A possible explanation for these discrepancies may be the highly dynamic and spatiotemporal nature of the epigenetic landscape, suggesting that several factors and features of stress response should be taken into account in the design of epigenetic studies to ensure comparative results $[46,128]$.

First, methodological variables related to stressor characteristics, such as the type, the duration and the timing of the stressful event, should be controlled and normalized across different studies to minimize background noise derived from the magnitude of the stress stimulus and the context-dependent conceptualization of threat that orchestrates the stress response [46]. Furthermore, the individual's characteristics, such as age, gender and genetic composition, may account for differences in epigenetic studies, as we have seen in the case of OXTR methylation status in females vs. males [76] and SLC6A4 methylation status in the presence of 5-HTTLPR S short allele [73].

Methodological differences between studies, including the tools stratified to measure certain types of adversities and the type of the study, cross-sectional vs. longitudinal, may account for divergent findings and are issues that should be addressed in future human epigenetic research [69]. In addition, the context-dependent nature of epigenetic modifications should be taken into account, given that epigenetic effects of stressors may not be the same across different tissues and may differ in peripheral blood versus tissues relevant to the stress-related disorders upon investigation $[46,129]$.

\section{Conclusions}

In this article, we present existing knowledge about epigenetic changes occurring in response to stress and their association with the emergence of stress-related disorders, focusing on GCs as primary mediators of these effects. Compelling evidence suggests that epigenetic modifications in stress-related genes involved in glucocorticoid signaling represent a mechanism through which stress-related experiences are embedded in an individual's biology. Epigenetic changes can influence the subsequent coping strategies [122] to stressors and, when accumulated, can contribute to the development of stress-related disorders [46]. A number of studies, claimed that epigenetic changes can actually be inherited to the next generation and as such parent's stressful experiences could influence offspring's 
vulnerability to many pathological conditions [57,130-132]. However, many researchers are sceptical about the potential of trauma inheritance through epigenome [133] and also highlight the need to perform epigenetic studies taking into account an individual's genetic background [134,135].

The imperfect fit of different epigenetic studies that follow a traditional reductionist paradigm, suggests that the interaction of stressors with the epigenome and its implication in the emergence of stress-related disorders is a much more complex network than previously thought, and demands our investigation in a context-specific and time-dependent manner. We hope that this article will help future studies, to build upon existing and novel findings their design, taking into account confounders that may bias study results, in order to delineate the mechanism linking stress exposure to epigenome and stress-related disorders development via the action of GCs.

Author Contributions: Conceptualization: N.M., E.C., Writing-Original draft preparation: N.M.; Writing-Review \& Editing: A.S., E.C. All authors have read and agreed to the published version of the manuscript.

Funding: This study was funded by internal funds of the Division of Endocrinology and Metabolism, Biomedical Research Foundation of the Academy of Athens, Athens, Greece.

Institutional Review Board Statement: Not applicable.

Informed Consent Statement: Not applicable.

Data Availability Statement: Data sharing not applicable.

Conflicts of Interest: The authors declare no conflict of interest.

\section{References}

1. Charmandari, E.; Tsigos, C.; Chrousos, G. Endocrinology of the stress response. Annu. Rev. Physiol. 2005, 67, 259-284. [CrossRef]

2. Chrousos, G.P. Stress and disorders of the stress system. Nat. Rev. Endocrinol. 2009, 5, 374-381. [CrossRef]

3. Zannas, A.S.; Chrousos, G.P. Epigenetic programming by stress and glucocorticoids along the human lifespan. Mol. Psychiatry 2017, 22, 640-646. [CrossRef]

4. Dupont, C.; Armant, D.R.; Brenner, C.A. Epigenetics: Definition, Mechanisms and Clinical Perspective. Semin. Reprod. Med. 2009, 27, 351-357. [CrossRef]

5. Habib, K.E.; Gold, P.W.; Chrousos, G.P. Neuroendocrinology of stress. Endocrinol. Metab. Clin. N. Am. 2001, 30, 695-728. [CrossRef]

6. Chrousos, G.P. Regulation and dysregulation of the hypothalamic-pituitary-adrenal axis. The corticotropin-releasing hormone perspective. Endocrinol. Metab. Clin. N. Am. 1992, 21, 833-858. [CrossRef]

7. Whitnall, M.H. Regulation of the hypothalamic corticotropin-releasing hormone neurosecretory system. Prog. Neurobiol. 1993, 40, 573-629. [CrossRef]

8. Nicolaides, N.C.; Kyratzi, E.; Lamprokostopoulou, A.; Chrousos, G.P.; Charmandari, E. Stress, the stress system and the role of glucocorticoids. Neuroimmunomodulation 2015, 22, 6-19. [CrossRef] [PubMed]

9. Ballard, P.L.; Baxter, J.D.; Higgins, S.J.; Rousseau, G.G.; Tomkins, G.M. General Presence of Glucocorticoid Receptors in Mammalian Tissues1. Endocrinology 1974, 94, 998-1002. [CrossRef] [PubMed]

10. Nicolaides, N.C.; Charmandari, E.; Chrousos, G.P.; Kino, T. Recent advances in the molecular mechanisms determining tissue sensitivity to glucocorticoids: Novel mutations, circadian rhythm and ligand-induced repression of the human glucocorticoid receptor. BMC Endocr. Disord. 2014, 14, 71. [CrossRef] [PubMed]

11. Newton, R. Molecular mechanisms of glucocorticoid action: What is important? Thorax 2000, 55, 603-613. [CrossRef]

12. Groeneweg, F.L.; Karst, H.; de Kloet, E.R.; Joëls, M. Rapid Non-Genomic Effects of Corticosteroids and Their Role in the Central Stress Response. J. Endocrinol. 2011, 209, pp. 153-167. Available online: https://joe.bioscientifica.com/view/journals/joe/209/2/ 153.xml (accessed on 15 March 2021).

13. Mechanisms of the Anti-Inflammatory Effects of Glucocorticoids: Genomic and Nongenomic Interference with MAPK

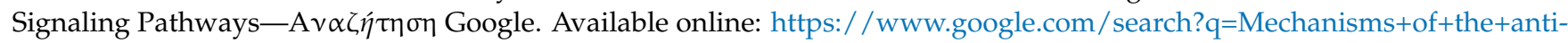
inflammatory+effects+of+glucocorticoids $\% 3 \mathrm{~A}+$ genomic+and+nongenomic+interference+with+MAPK+signaling+pathways\& rlz=1C5CHFA_enGR909GR909\&oq=Mechanisms+of +the+anti-inflammatory+effects+of +glucocorticoids \%3A+genomic + and+nongenomic+interference+with+MAPK+signaling+pathways\&aqs=chrome..69i57.801j0j7\&sourceid=chrome\&ie=UTF-8 (accessed on 15 March 2021).

14. Song, I.-H.; Buttgereit, F. Non-genomic glucocorticoid effects to provide the basis for new drug developments. Mol. Cell Endocrinol. 2006, 246, 142-146. [CrossRef] 
15. Nicolaides, N.C.; Kino, T.; Chrousos, G.; Charmandari, E. Primary Generalized Glucocorticoid Resistance or Chrousos Syndrome. In Endotext; Feingold, K.R., Anawalt, B., Boyce, A., Eds.; MDText.com, Inc.: South Dartmouth, MA, USA, 2000. Available online: http:/ / www.ncbi.nlm.nih.gov/books/NBK278930/ (accessed on 15 March 2021).

16. Buttgereit, F.; Scheffold, A. Rapid glucocorticoid effects on immune cells. Steroids 2002, 67, 529-534. [CrossRef]

17. Reul, J.M.; de Kloet, E.R. Two receptor systems for corticosterone in rat brain: Microdistribution and differential occupation. Endocrinology 1985, 117, 2505-2511. [CrossRef]

18. Grossmann, C.; Scholz, T.; Rochel, M.; Bumket-Vogt, C.; Oelkers, W.; Pfeiffer, A.F.H.; Diederich, S.; Bahr, V. Transactivation via the human glucocorticoid and mineralocorticoid receptor by therapeutically used steroids in CV-1 cells: A comparison of their glucocorticoid and mineralocorticoid properties. Eur. J. Endocrinol. 2004, 151, 397-406. [CrossRef]

19. Ter Heegde, F.; De Rijk, R.H.; Vinkers, C.H. The brain mineralocorticoid receptor and stress resilience. Psychoneuroendocrinology 2015, 52, 92-110. [CrossRef]

20. Latouche, C.; Sainte-Marie, Y.; Steenman, M.; Castro Chaves, P.; Naray-Fejes-Toth, A.; Fejes-Toth, G.; Farman, N.; Jaisser, F. Molecular signature of mineralocorticoid receptor signaling in cardiomyocytes: From cultured cells to mouse heart. Endocrinology 2010, 151, 4467-4476. [CrossRef] [PubMed]

21. Soundararajan, R.; Zhang, T.T.; Wang, J.; Vandewalle, A.; Pearce, D. A novel role for glucocorticoid-induced leucine zipper protein in epithelial sodium channel-mediated sodium transport. J. Biol. Chem. 2005, 280, 39970-39981. [CrossRef] [PubMed]

22. Mifsud, K.R.; Reul, J.M.H.M. Acute stress enhances heterodimerization and binding of corticosteroid receptors at glucocorticoid target genes in the hippocampus. Proc. Natl. Acad. Sci. USA 2016, 113, 11336-11341. [CrossRef] [PubMed]

23. Chen, S.; Bhargava, A.; Mastroberardino, L.; Meijer, O.C.; Wang, J.; Buse, P.; Firestone, G.L.; Verrey, F.; Pearce, D. Epithelial sodium channel regulated by aldosterone-induced protein sgk. Proc. Natl. Acad. Sci. USA 1999, 96, 2514-2519. [CrossRef]

24. Groeneweg, F.L.; Karst, H.; de Kloet, E.R.; Joëls, M. Mineralocorticoid and glucocorticoid receptors at the neuronal membrane, regulators of nongenomic corticosteroid signalling. Mol. Cell Endocrinol. 2012, 350, 299-309. [CrossRef]

25. Karst, H.; Berger, S.; Turiault, M.; Tronche, F.; Schütz, G.; Joëls, M. Mineralocorticoid receptors are indispensable for nongenomic modulation of hippocampal glutamate transmission by corticosterone. Proc. Natl. Acad. Sci. USA 2005, 102, 19204-19207. [CrossRef]

26. Karst, H.; Berger, S.; Erdmann, G.; Schütz, G.; Joëls, M. Metaplasticity of amygdalar responses to the stress hormone corticosterone. Proc. Natl. Acad. Sci. USA 2010, 107, 14449-14454. [CrossRef]

27. MR/GR Signaling in the Brain during the Stress Response I IntechOpen. Available online: https://www.intechopen.com/ books / aldosterone-mineralocorticoid-receptor-cell-biology-to-translational-medicine/mr-gr-signaling-in-the-brain-duringthe-stress-response (accessed on 17 March 2021).

28. Joëls, M.; Karst, H.; DeRijk, R.; de Kloet, E.R. The coming out of the brain mineralocorticoid receptor. Trends Neurosci. 2008, 31, 1-7. [CrossRef] [PubMed]

29. De Kloet, E.R.; Joëls, M.; Holsboer, F. Stress and the brain: From adaptation to disease. Nat. Rev. Neurosci. 2005, 6, 463-475. [CrossRef]

30. De Kloet, E.R.; Meijer, O.C.; de Nicola, A.F.; de Rijk, R.H.; Joëls, M. Importance of the brain corticosteroid receptor balance in metaplasticity, cognitive performance and neuro-inflammation. Front. Neuroendocrinol. 2018, 49, 124-145. [CrossRef]

31. Sarabdjitsingh, R.A.; Jezequel, J.; Pasricha, N.; Mikasova, L.; Kerkhofs, A.; Karst, H.; Groc, L.; Joels, M. Ultradian corticosterone pulses balance glutamatergic transmission and synaptic plasticity. Proc. Natl. Acad. Sci. USA 2014, 111, 14265-14270. [CrossRef]

32. De Kloet, E.R.; Reul, J.M. Feedback action and tonic influence of corticosteroids on brain function: A concept arising from the heterogeneity of brain receptor systems. Psychoneuroendocrinology 1987, 12, 83-105. [CrossRef]

33. Cornelisse, S.; Joëls, M.; Smeets, T. A Randomized Trial on Mineralocorticoid Receptor Blockade in Men: Effects on Stress Responses, Selective Attention, and Memory. Neuropsychopharmacology 2011, 36, 2720-2728. [CrossRef]

34. Korte, S.M.; De Boer, S.F.; De Kloet, E.R.; Bohus, B. Anxiolytic-like effects of selective mineralocorticoid and glucocorticoid antagonists on fear-enhanced behavior in the elevated plus-maze. Psychoneuroendocrinology 1995, 20, 385-394. [CrossRef]

35. Kruk, M.R.; Haller, J.; Meelis, W.; de Kloet, E.R. Mineralocorticoid receptor blockade during a rat's first violent encounter inhibits its subsequent propensity for violence. Behav. Neurosci. 2013, 127, 505-514. [CrossRef] [PubMed]

36. De Kloet, E.R.; Vreugdenhil, E.; Oitzl, M.S.; Joëls, M. Brain corticosteroid receptor balance in health and disease. Endocr. Rev. 1998, 19, 269-301. [CrossRef]

37. Russell, G.M.; Henley, D.E.; Leendertz, J.; Douthwaite, J.A.; Wood, S.A.; Stevens, A.; Woltersdorf, W.W.; Peeters, B.W.M.M.; Ruigt, G.S.F.; White, A.; et al. Rapid glucocorticoid receptor-mediated inhibition of hypothalamic-pituitary-adrenal ultradian activity in healthy males. J. Neurosci. Off. J. Soc. Neurosci. 2010, 30, 6106-6115. [CrossRef]

38. Keller-Wood, M.E.; Dallman, M.F. Corticosteroid inhibition of ACTH secretion. Endocr. Rev. 1984, 5, 1-24. [CrossRef]

39. Herman, J.P.; McKlveen, J.M.; Ghosal, S.; Kopp, B.; Wulsin, A.; Makinson, R.; Scheimann, J.; Myers, B. Regulation of the hypothalamic-pituitary-adrenocortical stress response. Compr. Physiol. 2016, 6, 603-621. [CrossRef]

40. Oitzl, M.S.; Reichardt, H.M.; Joëls, M.; de Kloet, E.R. Point mutation in the mouse glucocorticoid receptor preventing DNA binding impairs spatial memory. Proc. Natl. Acad. Sci. USA 2001, 98, 12790-12795. [CrossRef]

41. Henckens, M.J.A.G.; Pu, Z.; Hermans, E.J.; van Wingen, G.A.; Joëls, M.; Fernández, G. Dynamically changing effects of corticosteroids on human hippocampal and prefrontal processing. Hum. Brain Mapp. 2011, 33, 2885-2897. [CrossRef] 
42. Feng, X.; Zhao, Y.; Yang, T.; Song, M.; Wang, C.; Yao, Y.; Fan, H. Glucocorticoid-Driven NLRP3 Inflammasome Activation in Hippocampal Microglia Mediates Chronic Stress-Induced Depressive-Like Behaviors. Front. Mol. Neurosci. 2019, 12. [CrossRef]

43. Frank, M.G.; Hershman, S.A.; Weber, M.D.; Watkins, L.R.; Maier, S.F. Chronic exposure to exogenous glucocorticoids primes microglia to pro-inflammatory stimuli and induces NLRP3 mRNA in the hippocampus. Psychoneuroendocrinology 2014, 40, 191-200. [CrossRef]

44. Frank, M.G.; Watkins, L.R.; Maier, S.F. The permissive role of glucocorticoids in neuroinflammatory priming: Mechanisms and insights. Curr. Opin. Endocrinol. Diabetes Obes. 2015, 22, 300-305. [CrossRef] [PubMed]

45. De Kloet, E.R.; Meijer, O.C. MR/GR Signaling in the Brain during the Stress Response. Aldosterone-Miner. Recept Cell Biol. Transl. Med. 2019. [CrossRef]

46. Gassen, N.C.; Chrousos, G.P.; Binder, E.B.; Zannas, A.S. Life stress, glucocorticoid signaling, and the aging epigenome: Implications for aging-related diseases. Neurosci. Biobehav. Rev. 2017, 74 Pt B, 356-365. [CrossRef]

47. Herceg, Z. Epigenetic Mechanisms as an Interface Between the Environment and Genome. In Hypoxia: Translation in Progress; Roach, R.C., Hackett, P.H., Wagner, P.D., Eds.; Advances in Experimental Medicine and Biology; Springer US: New York, NY, USA, 2016; pp. 3-15. [CrossRef]

48. Bagot, R.C.; Labonté, B.; Peña, C.J.; Nestler, E.J. Epigenetic signaling in psychiatric disorders: Stress and depression. Dialogues Clin. Neurosci. 2014, 16, 281-295.

49. Alyamani, R.A.S.; Murgatroyd, C. Epigenetic Programming by Early-Life Stress. Prog. Mol. Biol. Transl. Sci. 2018, 157, 133-150. [CrossRef]

50. Wiechmann, T.; Röh, S.; Sauer, S.; Czamara, D.; Arloth, J.; Ködel, M.; Beintner, M.; Knop, L.; Menke, A.; Binder, E.B.; et al. Identification of dynamic glucocorticoid-induced methylation changes at the FKBP5 locus. Clin. Epigenet. 2019, 11, 83. [CrossRef]

51. Park, C.; Rosenblat, J.D.; Brietzke, E.; Pan, Z.; Lee, Y.; Cao, B.; Zuckerman, H.; Kalantarova, A.; McIntyre, R.S. Stress, epigenetics and depression: A systematic review. Neurosci. Biobehav. Rev. 2019, 102, 139-152. [CrossRef]

52. Uht, R.M. Mechanisms of Glucocorticoid Receptor (GR) Mediated Corticotropin Releasing Hormone Gene Expression. Glucocorticoids New Recognit. Fam. Friend 2012. [CrossRef]

53. Dwivedi, Y.; Roy, B.; Lugli, G.; Rizavi, H.; Zhang, H.; Smalheiser, N.R. Chronic corticosterone-mediated dysregulation of microRNA network in prefrontal cortex of rats: Relevance to depression pathophysiology. Transl. Psychiatry 2015, 5, e682. [CrossRef] [PubMed]

54. Vockley, C.M.; D’Ippolito, A.M.; McDowell, I.C.; Majoros, W.H.; Safi, A.; Song, L.; Crawford, G.E.; Reddy, T.E. Direct GR binding sites potentiate clusters of TF binding across the human genome. Cell 2016, 166, 1269-1281.e19. [CrossRef]

55. Non, A.L.; Binder, A.M.; Kubzansky, L.D.; Michels, K.B. Genome-wide DNA methylation in neonates exposed to maternal depression, anxiety, or SSRI medication during pregnancy. Epigenetics 2014, 9, 964-972. [CrossRef]

56. Jiang, S.; Postovit, L.; Cattaneo, A.; Binder, E.B.; Aitchison, K.J. Epigenetic Modifications in Stress Response Genes Associated With Childhood Trauma. Front. Psychiatry 2019, 10. [CrossRef] [PubMed]

57. Schiele, M.A.; Gottschalk, M.G.; Domschke, K. The applied implications of epigenetics in anxiety, affective and stress-related disorders-A review and synthesis on psychosocial stress, psychotherapy and prevention. Clin. Psychol. Rev. 2020, 77, 101830. [CrossRef]

58. FKBP5 Allele-Specific Epigenetic Modification in Gene by Environment Interaction-PubMed. Available online: https://pubmed. ncbi.nlm.nih.gov/25482174/ (accessed on 26 March 2021).

59. Zannas, A.S.; Wiechmann, T.; Gassen, N.C.; Binder, E.B. Gene-Stress-Epigenetic Regulation of FKBP5: Clinical and Translational Implications. Neuropsychopharmacology 2016, 41, 261-274. [CrossRef]

60. Scharf, S.H.; Liebl, C.; Binder, E.B.; Schmidt, M.V.; Müller, M.B. Expression and Regulation of the Fkbp5 Gene in the Adult Mouse Brain. PLoS ONE 2011, 6, e16883. [CrossRef]

61. van der Knaap, L.J.; Riese, H.; Hudziak, J.J.; Verbiest, M.M.P.J.; Verhulst, F.C.; Oldehinkel, A.J. Glucocorticoid receptor gene (NR3C1) methylation following stressful events between birth and adolescence. The TRAILS study. Transl. Psychiatry 2014, 4, e381. [CrossRef]

62. Vukojevic, V.; Kolassa, I.-T.; Fastenrath, M.; Gschwind, L.; Spalek, K.; Milnik, A.; Heck, A.; Vogler, C.; Wilker, S.; Demougin, P.; et al. Epigenetic Modification of the Glucocorticoid Receptor Gene Is Linked to Traumatic Memory and Post-Traumatic Stress Disorder Risk in Genocide Survivors. J. Neurosci. 2014, 34, 10274-10284. [CrossRef]

63. Jimeno, B.; Hau, M.; Gómez-Díaz, E.; Verhulst, S. Developmental conditions modulate DNA methylation at the glucocorticoid receptor gene with cascading effects on expression and corticosterone levels in zebra finches. Sci. Rep. 2019, 9, 15869. [CrossRef]

64. Ferrer, A.; Labad, J.; Salvat-Pujol, N.; Barrachina, M.; Costas, J.; Urretavizcaya, M.; de Arriba-Arnau, A.; Crespo, J.M.; Soriano-Mas, C.; Carracedo, Á.; et al. BDNF genetic variants and methylation: Effects on cognition in major depressive disorder. Transl. Psychiatry 2019, 9, 1-10. [CrossRef]

65. Fachim, H.A.; Corsi-Zuelli, F.; Loureiro, C.M.; Iamjan, S.-A.; Shuhama, R.; Joca, S.; Menezes, P.R.; Heald, A.; Louzada-Junior, P.; Dalton, C.F.; et al. Early-Life Stress Effects on BDNF DNA Methylation in First-Episode Psychosis and in Rats Reared in Isolation. Prog. Neuro-Psychopharmacol. Biol. Psychiatry 2021, 108, 110188. [CrossRef]

66. Roth, T.L.; Zoladz, P.R.; Sweatt, J.D.; Diamond, D.M. Epigenetic Modification of Hippocampal Bdnf DNA in Adult Rats in an Animal Model of Post-Traumatic Stress Disorder. J. Psychiatr. Res. 2011, 45, 919-926. [CrossRef] 
67. Voisey, J.; Lawford, B.; Bruenig, D.; Harvey, W.; Morris, C.P.; Young, R.M.; Mehta, D.; PTSD Initiative. Differential BDNF methylation in combat exposed veterans and the association with exercise. Gene 2019, 698, 107-112. [CrossRef]

68. Fuchikami, M.; Yamamoto, S.; Morinobu, S.; Takei, S.; Yamawaki, S. Epigenetic Regulation of BDNF Gene in Response to Stress. Psychiatry Investig. 2010, 7, 251-256. [CrossRef]

69. Provenzi, L.; Giorda, R.; Beri, S.; Montirosso, R. SLC6A4 methylation as an epigenetic marker of life adversity exposures in humans: A systematic review of literature. Neurosci. Biobehav. Rev. 2016, 71, 7-20. [CrossRef]

70. Kang, H.-J.; Kim, J.-M.; Stewart, R.; Kim, S.-Y.; Bae, K.-Y.; Kim, S.-W.; Shin, I.-S.; Shin, M.-G.; Yoon, J.-S. Association of SLC6A4 methylation with early adversity, characteristics and outcomes in depression. Prog. Neuro-Psychopharmacol. Biol. Psychiatry 2013, 44, 23-28. [CrossRef]

71. Booij, L.; Szyf, M.; Carballedo, A.; Frey, E.-M.; Morris, D.; Dymov, S.; Vaisheva, F.; Ly, V.; Fahey, C.; Meaney, J.; et al. DNA methylation of the serotonin transporter gene in peripheral cells and stress-related changes in hippocampal volume: A study in depressed patients and healthy controls. PLoS ONE 2015, 10, e0119061. [CrossRef]

72. van der Knaap, L.J.; Riese, H.; Hudziak, J.J.; Verbiest, M.M.P.J.; Verhulst, F.C.; Oldehinkel, A.J.; van Oort, F.V.A. Adverse life events and allele-specific methylation of the serotonin transporter gene (SLC6A4) in adolescents: The TRAILS study. Psychosom. Med. 2015, 77, 246-255. [CrossRef]

73. Alasaari, J.S.; Lagus, M.; Ollila, H.M.; Toivola, A.; Kivimäki, M.; Vahtera, J.; Kronholm, E.; Härmä, M.; Puttonen, S.; Paunio, T. Environmental Stress Affects DNA Methylation of a CpG Rich Promoter Region of Serotonin Transporter Gene in a Nurse Cohort. PLoS ONE 2012, 7, e45813. [CrossRef]

74. Wang, D.; Liu, X.; Zhou, Y.; Xie, H.; Hong, X.; Tsai, H.-J.; Wang, G.; Liu, R.; Wang, X. Individual variation and longitudinal pattern of genome-wide DNA methylation from birth to the first two years of life. Epigenetics 2012, 7, 594-605. [CrossRef]

75. Duman, E.A.; Canli, T. Influence of life stress, 5-HTTLPR genotype, and SLC6A4 methylation on gene expression and stress response in healthy Caucasian males. Biol. Mood Anxiety Disord. 2015, 5. [CrossRef]

76. Kraaijenvanger, E.J.; He, Y.; Spencer, H.; Smith, A.K.; Bos, P.A.; Boks, M.P.M. Epigenetic Variability in the Human Oxytocin Receptor (OXTR) Gene: A Possible Pathway from Early Life Experiences to Psychopathologies. Neurosci. Biobehav. Rev. 2019, 96, 127-142. [CrossRef]

77. Thaler, L.; Brassard, S.; Booij, L.; Kahan, E.; McGregor, K.; Labbe, A.; Israel, M.; Steiger, H. Methylation of the OXTR gene in women with anorexia nervosa: Relationship to social behavior. Eur. Eat. Disord. Rev. J. Eat. Disord. Assoc. 2020, $28,79-86$. [CrossRef] [PubMed]

78. Andari, E.; Nishitani, S.; Kaundinya, G.; Caceres, G.A.; Morrier, M.J.; Ousley, O.; Smith, A.K.; Cubells, J.F.; Young, L. Epigenetic modification of the oxytocin receptor gene: Implications for autism symptom severity and brain functional connectivity. Neuropsychopharmacol. Off. Publ. Am. Coll. Neuropsychopharmacol. 2020, 45, 1150-1158. [CrossRef] [PubMed]

79. Maud, C.; Ryan, J.; McIntosh, J.E.; Olsson, C.A. The role of oxytocin receptor gene (OXTR) DNA methylation (DNAm) in human social and emotional functioning: A systematic narrative review. BMC Psychiatry 2018, 18. [CrossRef]

80. Kusui, C.; Kimura, T.; Ogita, K.; Nakamura, H.; Matsumura, Y.; Koyama, M.; Azuma, C.; Murata, Y. DNA methylation of the human oxytocin receptor gene promoter regulates tissue-specific gene suppression. Biochem. Biophys. Res. Commun. 2001, 289, 681-686. [CrossRef]

81. Saito, T.; Shinozaki, G.; Koga, M.; Tanichi, M.; Takeshita, S.; Nakagawa, R.; Nagamine, M.; Cho, H.R.; Morimoto, Y.; Kobayashi, Y.; et al. Effect of interaction between a specific subtype of child abuse and the FKBP5 rs1360780 SNP on DNA methylation among patients with bipolar disorder. J. Affect. Disord. 2020, 272, 417-422. [CrossRef]

82. Misiak, B.; Karpiński, P.; Szmida, E.; Grą́lewski, T.; Jabłoński, M.; Cyranka, K.; Rymaszewska, J.; Piotrowski, P.; Kotowicz, K.; Frydecka, D. Adverse Childhood Experiences and Methylation of the FKBP5 Gene in Patients with Psychotic Disorders. J. Clin. Med. 2020, 9, 3792. [CrossRef]

83. Ramo-Fernández, L.; Boeck, C.; Koenig, A.M.; Schury, K.; Binder, E.B.; Gündel, H.; Fegert, J.M.; Karabatsiakis, A.; Kolassa, I.-T. The effects of childhood maltreatment on epigenetic regulation of stress-response associated genes: An intergenerational approach. Sci. Rep. 2019, 9. [CrossRef]

84. Borçoi, A.R.; Mendes, S.O.; Moreno, I.A.A.; Gasparini Dos Santos, J.; Freitas, F.V.; Pinheiro, J.A.; de Oliveira, M.M.; Barbosa, W.M.; Arpini, J.K.; Archanjo, A.B.; et al. Food and nutritional insecurity is associated with depressive symptoms mediated by NR3C1 gene promoter 1F methylation. Stress 2021, 1-8. [CrossRef]

85. De Assis Pinheiro, J.; Freitas, F.V.; Borçoi, A.R.; Mendes, S.O.; Conti, C.L.; Arpini, J.K.; Dos Santos Vieira, T.; de Souza, R.A.; Dos Santos, D.P.; Barbosa, W.M.; et al. Alcohol consumption, depression, overweight and cortisol levels as determining factors for NR3C1 gene methylation. Sci. Rep. 2021, 11, 6768. [CrossRef]

86. Misiak, B.; Samochowiec, J.; Konopka, A.; Gawrońska-Szklarz, B.; Beszłej, J.A.; Szmida, E.; Karpiński, P. Clinical correlates of the NR3C1 gene methylation at various stages of psychosis. Int. J. Neuropsychopharmacol. 2020, 24. [CrossRef]

87. Duffy, H.B.D.; Roth, T.L. Increases in Bdnf DNA Methylation in the Prefrontal Cortex Following Aversive Caregiving Are Reflected in Blood Tissue. Front. Hum. Neurosci. 2020, 14, 594244. [CrossRef] [PubMed]

88. Blaze, J.; Roth, T.L. Caregiver maltreatment causes altered neuronal DNA methylation in female rodents. Dev. Psychopathol. 2017, 29, 477-489. [CrossRef] [PubMed]

89. Niknazar, S.; Nahavandi, A.; Peyvandi, A.A.; Peyvandi, H.; Zare Mehrjerdi, F.; Karimi, M. Effect of Maternal Stress Prior to Conception on Hippocampal BDNF Signaling in Rat Offspring. Mol. Neurobiol. 2017, 54, 6436-6445. [CrossRef] 
90. DeLano, K.; Folger, A.T.; Ding, L.; Ji, H.; Yolton, K.; Ammerman, R.T.; Van Ginkel, J.B.; Bowers, K.A. Associations Between Maternal Community Deprivation and Infant DNA Methylation of the SLC6A4 Gene. Front. Public Health 2020, 8. [CrossRef] [PubMed]

91. Timothy, A.; Benegal, V.; Shankarappa, B.; Saxena, S.; Jain, S.; Purushottam, M. Influence of early adversity on cortisol reactivity, SLC6A4 methylation and externalizing behavior in children of alcoholics. Prog. Neuro-Psychopharmacol. Biol. Psychiatry 2019, 94 [CrossRef]

92. Smith, J.A.; Zhao, W.; Wang, X.; Ratliff, S.M.; Mukherjee, B.; Kardia, S.L.R.; Liu, Y.; Roux, A.V.D.; Needham, B.L. Neighborhood characteristics influence DNA methylation of genes involved in stress response and inflammation: The Multi-Ethnic Study of Atherosclerosis. Epigenetics 2017, 12, 662-673. [CrossRef] [PubMed]

93. Kogan, S.M.; Bae, D.; Cho, J.; Smith, A.K.; Nishitani, S. Childhood Adversity, Socioeconomic Instability, Oxytocin-Receptor-Gene Methylation, and Romantic-Relationship Support Among Young African American Men. Psychol. Sci. 2019, 30, 1234-1244. [CrossRef]

94. Kogan, S.M.; Cho, J.; Beach, S.R.H.; Smith, A.K.; Nishitani, S. Oxytocin receptor gene methylation and substance use problems among young African American men. Drug Alcohol Depend. 2018, 192, 309-315. [CrossRef]

95. Gouin, J.P.; Zhou, Q.Q.; Booij, L.; Boivin, M.; Côté, S.M.; Hébert, M.; Ouellet-Morin, I.; Szyf, M.; Tremblay, R.E.; Turecki, G.; et al. Associations among oxytocin receptor gene (OXTR) DNA methylation in adulthood, exposure to early life adversity, and childhood trajectories of anxiousness. Sci. Rep. 2017, 7. [CrossRef]

96. Klengel, T.; Binder, E.B. Allele-specific epigenetic modification: A molecular mechanism for gene-environment interactions in stress-related psychiatric disorders? Epigenomics 2013, 5, 109-112. [CrossRef]

97. Daskalakis, N.P.; Yehuda, R. Site-specific methylation changes in the glucocorticoid receptor exon $1 F$ promoter in relation to life adversity: Systematic review of contributing factors. Front. Neurosci. 2014, 8. [CrossRef] [PubMed]

98. Cicchetti, D.; Handley, E.D. Methylation of the glucocorticoid receptor gene (NR3C1) in maltreated and nonmaltreated children: Associations with behavioral undercontrol, emotional lability/negativity, and externalizing and internalizing symptoms. Dev. Psychopathol. 2017, 29, 1795-1806. [CrossRef]

99. Tyrka, A.R.; Parade, S.H.; Eslinger, N.M.; Marsit, C.J.; Lesseur, C.; Armstrong, D.A.; Philip, N.S.; Josefson, B.; Seifer, R. Methylation of Exons 1D, 1F, and 1H of the Glucocorticoid Receptor Gene Promoter and Exposure to Adversity in Pre-School Aged Children. Dev. Psychopathol. 2015, 27, 577-585. [CrossRef] [PubMed]

100. Palma-Gudiel, H.; Córdova-Palomera, A.; Leza, J.C.; Fañanás, L. Glucocorticoid receptor gene (NR3C1) methylation processes as mediators of early adversity in stress-related disorders causality: A critical review. Neurosci. Biobehav. Rev. 2015, 55, 520-535. [CrossRef] [PubMed]

101. Onishchenko, N.; Karpova, N.; Sabri, F.; Castrén, E.; Ceccatelli, S. Long-lasting depression-like behavior and epigenetic changes of BDNF gene expression induced by perinatal exposure to methylmercury. J. Neurochem. 2008, 106, 1378-1387. [CrossRef]

102. Tsankova, N.M.; Berton, O.; Renthal, W.; Kumar, A.; Neve, R.L.; Nestler, E.J. Sustained hippocampal chromatin regulation in a mouse model of depression and antidepressant action. Nat. Neurosci. 2006, 9, 519-525. [CrossRef]

103. Miao, Z.; Wang, Y.; Sun, Z. The Relationships Between Stress, Mental Disorders, and Epigenetic Regulation of BDNF. Int. J. Mol. Sci. 2020, 21, 1375. [CrossRef]

104. Dwivedi, Y.; Rizavi, H.S.; Conley, R.R.; Roberts, R.C.; Tamminga, C.A.; Pandey, G.N. Altered gene expression of brain-derived neurotrophic factor and receptor tyrosine kinase B in postmortem brain of suicide subjects. Arch. Gen. Psychiatry 2003, 60, 804-815. [CrossRef]

105. Molendijk, M.; Bus, B.A.; Spinhoven, P.; Penninx, B.W.; Kenis, G.; Prickaerts, J.; Voshaar, R.O.; Elzinga, B. Serum levels of brain-derived neurotrophic factor in major depressive disorder: State-trait issues, clinical features and pharmacological treatment. Mol. Psychiatry 2011, 16, 1088-1095. [CrossRef]

106. Gören, J.L. Brain-derived neurotrophic factor and schizophrenia. Ment. Health Clin. 2016, 6, 285-288. [CrossRef]

107. Ursini, G.; Cavalleri, T.; Fazio, L.; Angrisano, T.; Iacovelli, L.; Porcelli, A.; Maddalena, G.; Punzi, G.; Mancini, M.; Gelao, B.; et al. BDNF rs6265 methylation and genotype interact on risk for schizophrenia. Epigenetics 2016, 11, 11-23. [CrossRef]

108. Mill, J.; Tang, T.; Kaminsky, Z.; Khare, T.; Yazdanpanah, S.; Bouchard, L.; Jia, P.; Assadzadeh, A.; Flanagan, J.; Schumacher, A.; et al. Epigenomic Profiling Reveals DNA-Methylation Changes Associated with Major Psychosis. Am. J. Hum. Genet. 2008, 82, 696-711. [CrossRef]

109. Silva, R.C.; Maffioletti, E.; Gennarelli, M.; Baune, B.T.; Minelli, A. Biological correlates of early life stressful events in major depressive disorder. Psychoneuroendocrinology 2021, 125, 105103. [CrossRef]

110. Swartz, J.R.; Hariri, A.R.; Williamson, D.E. An epigenetic mechanism links socioeconomic status to changes in depression-related brain function in high-risk adolescents. Mol. Psychiatry 2017, 22, 209-214. [CrossRef]

111. Olsson, C.A.; Foley, D.L.; Parkinson-Bates, M.; Byrnes, G.; McKenzie, M.; Patton, G.C.; Morley, R.; Anney, R.J.L.; Craig, J.M.; Saffery, R. Prospects for epigenetic research within cohort studies of psychological disorder: A pilot investigation of a peripheral cell marker of epigenetic risk for depression. Biol. Psychol. 2010, 83, 159-165. [CrossRef]

112. Lei, M.-K.; Beach, S.R.H.; Simons, R.L.; Philibert, R.A. Neighborhood crime and depressive symptoms among African American women: Genetic moderation and epigenetic mediation of effects. Soc. Sci. Med. 2015, 146, 120-128. [CrossRef]

113. Simons, R.L.; Lei, M.K.; Beach, S.R.H.; Cutrona, C.E.; Philibert, R.A. Methylation of the oxytocin receptor gene mediates the effect of adversity on negative schemas and depression. Dev. Psychopathol. 2017, 29, 725-736. [CrossRef] 
114. Smearman, E.L.; Almli, L.M.; Conneely, K.N.; Brody, G.H.; Sales, J.M.; Bradley, B.; Ressler, K.J.; Smith, A.K. Oxytocin Receptor Genetic and Epigenetic Variations: Association With Child Abuse and Adult Psychiatric Symptoms. Child. Dev. 2016, 87, 122-134. [CrossRef]

115. Mihaljevic, M.; Franic, D.; Soldatovic, I.; Lukic, I.; Petrovic, S.A.; Mirjanic, T.; Stankovic, B.; Zukic, B.; Zeljic, K.; Gasic, V.; et al. The FKBP5 genotype and childhood trauma effects on FKBP5 DNA methylation in patients with psychosis, their unaffected siblings, and healthy controls. Psychoneuroendocrinology 2021, 128, 105205. [CrossRef]

116. Kang, J.I.; Kim, T.Y.; Choi, J.H.; So, H.S.; Kim, S.J. Allele-specific DNA methylation level of FKBP5 is associated with post-traumatic stress disorder. Psychoneuroendocrinology 2019, 103, 1-7. [CrossRef]

117. Klinger-König, J.; Hertel, J.; Van der Auwera, S.; Frenzel, S.; Pfeiffer, L.; Waldenberger, M.; Golchert, J.; Teumer, A.; Nauck, M.; Homuth, G.; et al. Methylation of the FKBP5 gene in association with FKBP5 genotypes, childhood maltreatment and depression. Neuropsychopharmacology 2019, 44, 930-938. [CrossRef]

118. Bakusic, J.; Vrieze, E.; Ghosh, M.; Bekaert, B.; Claes, S.; Godderis, L. Increased methylation of NR3C1 and SLC6A4 is associated with blunted cortisol reactivity to stress in major depression. Neurobiol. Stress 2020, 13, 100272. [CrossRef]

119. Guo, J.; Yang, Y.; Jiang, X.; Guo, M.; Li, X.; Huang, P.; Liu, Z. Differential promoter methylation and G-712A polymorphism of brain-derived neurotrophic factor in post-traumatic stress disorder patients of $\mathrm{Li}$ and Han populations in Hainan province. Gene 2021, 769. [CrossRef]

120. Hossack, M.R.; Reid, M.W.; Aden, J.K.; Gibbons, T.; Noe, J.C.; Willis, A.M. Adverse Childhood Experience, Genes, and PTSD Risk in Soldiers: A Methylation Study. In Military Medicine; Oxford University Press: Oxford, UK, 2020; Volume 185, pp. 377-384. [CrossRef]

121. Peng, H.; Zhu, Y.; Strachan, E.; Fowler, E.; Bacus, T.; Roy-Byrne, P.; Goldberg, J.; Vaccarino, V.; Zhao, J. Childhood Trauma, DNA Methylation of Stress-Related Genes, and Depression: Findings from Two Monozygotic Twin Studies. Psychosom. Med. 2018, 80, 599-608. [CrossRef]

122. Shirata, T.; Suzuki, A.; Matsumoto, Y.; Noto, K.; Goto, K.; Otani, K. Interrelation between increased bdnf gene methylation and high sociotropy, a personality vulnerability factor in cognitive model of depression. Neuropsychiatr. Dis. Treat. 2020, 16, 1257-1263. [CrossRef]

123. Sanwald, S.; Widenhorn-Müller, K.; Schönfeldt-Lecuona, C.; GenEmo Research Group; Montag, C.; Kiefer, M. Factors related to age at depression onset: The role of SLC6A4 methylation, sex, exposure to stressful life events and personality in a sample of inpatients suffering from major depression. BMC Psychiatry 2021, 21. [CrossRef]

124. Schneider, I.; Kugel, H.; Redlich, R.; Grotegerd, D.; Bürger, C.; Bürkner, P.-C.; Opel, N.; Dohm, K.; Zaremba, D.; Meinert, S.; et al. Association of Serotonin Transporter Gene AluJb Methylation with Major Depression, Amygdala Responsiveness, 5-HTTLPR/rs25531 Polymorphism, and Stress. Neuropsychopharmacology 2018, 43, 1308-1316. [CrossRef]

125. Nawijn, L.; Krzyzewska, I.M.; van Zuiden, M.; Henneman, P.; Koch, S.B.J.; Mul, A.N.; Frijling, J.L.; Veltman, D.J.; Mannens, M.M.A.M.; Olff, M. Oxytocin receptor gene methylation in male and female PTSD patients and trauma-exposed controls. Eur. Neuropsychopharmacol. 2019, 29, 147-155. [CrossRef]

126. Ein-Dor, T.; Verbeke, W.J.M.I.; Mokry, M.; Vrtička, P. Epigenetic modification of the oxytocin and glucocorticoid receptor genes is linked to attachment avoidance in young adults. Attach. Hum. Dev. 2018, 20, 439-454. [CrossRef]

127. Cappi, C.; Diniz, J.B.; Requena, G.L.; Lourenço, T.; Lisboa, B.C.G.; Batistuzzo, M.C.; Marques, A.H.; Hoexter, M.Q.; Pereira, C.A.; Miguel, E.C.; et al. Epigenetic evidence for involvement of the oxytocin receptor gene in obsessive-compulsive disorder. $B M C$ Neurosci. 2016, 17. [CrossRef] [PubMed]

128. Agorastos, A.; Pervanidou, P.; Chrousos, G.P.; Baker, D.G. Developmental Trajectories of Early Life Stress and Trauma: A Narrative Review on Neurobiological Aspects Beyond Stress System Dysregulation. Front. Psychiatry 2019, 10. [CrossRef]

129. Hack, L.M.; Dick, A.L.W.; Provençal, N. Epigenetic mechanisms involved in the effects of stress exposure: Focus on 5hydroxymethylcytosine. Environ. Epigenet. 2016, 2. [CrossRef]

130. Yehuda, R.; Daskalakis, N.P.; Bierer, L.M.; Bader, H.N.; Klengel, T.; Holsboer, F.; Binder, E.B. Holocaust Exposure Induced Intergenerational Effects on FKBP5 Methylation. Biol. Psychiatry 2016, 80, 372-380. [CrossRef]

131. Pang, T.Y.C.; Short, A.K.; Bredy, T.W.; Hannan, A.J. Transgenerational paternal transmission of acquired traits: Stress-induced modification of the sperm regulatory transcriptome and offspring phenotypes. Curr. Opin. Behav. Sci. 2017, 14, 140-147. [CrossRef]

132. Saavedra-Rodríguez, L.; Feig, L.A. Chronic social instability induces anxiety and defective social interactions across generations Biol. Psychiatry 2013, 73, 44-53. [CrossRef]

133. Why I'm Sceptical about the Idea of Genetically Inherited Trauma. The Guardian, 11 September $2015 . \quad$ Available online: http://www.theguardian.com/science/blog/2015/sep/11/why-im-sceptical-about-the-idea-of-genetically-inheritedtrauma-epigenetics (accessed on 16 May 2021).

134. Birney, E. Chromatin and heritability: How epigenetic studies can complement genetic approaches. Trends Genet. TIG 2011, 27, 172-176. [CrossRef] [PubMed]

135. Relton, C.L.; Smith, G.D. Epigenetic Epidemiology of Common Complex Disease: Prospects for Prediction, Prevention, and Treatment. PLoS Med. 2010, 7, e1000356. [CrossRef] [PubMed] 